\title{
APLIKASI PENYEWAAN FASILITAS UMUM PADA BALAI PENGEMBANGAN PENDIDIKAN ANAK USIA DINI DAN PENDIDIKAN MASYARAKAT PROVINSI KALIMANTAN TENGAH BERBASIS WEBSITE
}

\author{
Putu Bagus Adidyana Anugrah Putra ${ }^{\mathrm{a}, 1}$, Widiatry b,2,* \\ ${ }^{a}$ Universitas Palangka Raya, Kampus Tunjung Nyaho Jalan Yos Sudarso, Palangka Raya, Kalimantan Tengah, Indonesia \\ ${ }^{\mathrm{b}}$ Universitas Palangka Raya, Kampus Tunjung Nyaho Jalan Yos Sudarso, Palangka Raya, Kalimantan Tengah, Indonesia \\ ${ }^{1}$ putubagus@it.upr.ac.id, ${ }^{2}$ widiatry@it.upr.ac.id* \\ * corresponding author
}

ARTICLE INFO

Keywords

Website

Software

Waterfall

\section{ABSTRACT}

Department of Early Childhood Education Development and Community Education (BP PAUD and Dikmas) Central Kalimantan Province is the Technical Implementation Unit (UPT) of the Directorate General of Early Childhood Education and Community Education (PAUD and Dikmas) of the Ministry of Education and Culture. Several facilities can be rented out to the public at the agency, such as halls, dormitories, and guest houses. There are still many people who do not know this public facility that can be used. The rental process is still done manually by coming directly or sending a letter of application. In terms of bookkeeping, sometimes there are some data recording errors. Therefore, a website was developed that can help provide information on what public facilities can be used for the public and used to carry out the rental process to help the community make rentals without having to come directly to BP PAUD and Dikmas. Developing this website using the Waterfall software development methodology has stages, namely Requirements Definition, which is done by making Flowcharts. System and Software Design is carried out by making Data Flow Diagrams (DFD) and Entity Relationship Diagrams (ERD), Implementation and Unit Testing with the programming languages used, namely HTML, PHP, CSS, Bootstrap, Javascript and MySQL and Integration and System Testing. The testing method used is the Blackbox method.

Based on the test results, it can be concluded that this website can run according to its function. The final result of this program also shows the achievement of the objectives that have been implemented, such as the presence of several features that are used appropriately according to their use.

\section{Pendahuluan}

Perkembangan ilmu pengetahuan dan teknologi komunikasi berkembang begitu pesat dengan banyak bermunculannya berbagai alat telekomunikasi atau penghubung yang canggih Pemanfaatan teknologi informasi dan internet dapat digunakan sebagai sarana memperoleh informasi-informasi. Internet merupakan sarana yang cepat dan mudah dalam menyebarkan informasi dan mencari informasi yang dibutuhkan dengan mengunjungi situs atau website. Oleh karena itu website dianggap efektif untuk melakukan publikasi dan pemasaran informasi baik organisasi, lembaga, instansi pemerintahan atau yang bersifat informasi untuk umum [1].

Balai Pengembangan Pendidikan Anak Usia Dini dan Pendidikan Masyarakat (BP PAUD dan Dikmas) Provinsi Kalimantan Tengah merupakan Unit Pelaksana Teknis (UPT) Ditjen Pendidikan Anak Usia Dini dan Pendidikan Masyarakat (PAUD dan Dikmas) Kementerian Pendidikan dan Kebudayaan. Pada instansi tersebut terdapat beberapa fasilitas yang dapat disewakan untuk umum 
seperti asrama dan guest house kepada para tamu dari luar daerah yang menghadiri beberapa kegiatan yang dilaksanakan oleh BP PAUD dan Dikmas setiap tahunnya dan beberapa fasilitas seperti aula dan dapur umum yang juga dapat digunakan oleh masyarakat umum.

Pada saat ini masih banyak masyarakat yang belum mengetahui fasilitas umum yang dapat digunakan ini. Proses penyewaan pun masih dilakukan secara manual dengan datang langsung atau mengirimkan surat permohonan. Dalam hal pembukuan juga terkadang terdapat beberapa kesalahan pencatatan data. Dengan latar belakang tersebut maka dibuat suatu website yang dapat membantu memberikan informasi fasiltas umum apa saja yang dapat digunakan untuk umum dan juga digunakan untuk melakukan proses penyewaan sehingga dapat membantu masyarakat untuk melakukan penyewaan tanpa harus datang langsung ke BP PAUD dan Dikmas. Untuk BP PAUD dan Dikmas juga dapat membuat catatan pembukuan dalam penggunaan fasilitas menjadi lebih baik. Aplikasi berbasis website ini dibuat menggunakan bahasa pemrograman PHP dan database MySQL[2][3].

Sehubungan dengan bagaimana membuat analisis dan desain suatu aplikasi, maka peneliti telah melakukan beberapa penelitian terdahulu yaitu Analisis dan Desain Perangkat Lunak Generate File Akun Uang Kuliah Tunggal (UKT) Universitas Palangka Raya[4] dan Sistem Informasi Kepegawaian UPT Kesatuan Pengelolaan Hutan Produksi Kapuas Tengah UNIT XI [5]. Sebagai referensi juga yang digunakan untuk mengembangkan aplikasi berbasis website ini, peneliti telah melakukan penelitian terdahulu yaitu Perancangan Perangkat Lunak Pendaftaran dan Penjadwalan Ujian Skripsi Pada Fakultas Kedokteran Universitas Palangka Raya Berbasis Website [6], Rancang Bangun Website ELearning SMAN 1 Palangka Raya [7], dan Pengembangan Website Pengelolaan Praktikum Pada Program Studi Biologi Fakultas Matematika Dan Ilmu Pengetahuan Alam Universitas Palangka Raya [8].

\section{Metodologi Penelitian}

Dalam mengembangkan aplikasi berbasis website ini peneliti menggunakan metode waterfall dengan tahapan yaitu requirements definition, system and software design, implementation and unit testing, integration and system testing, dan operation and maintenance [9], dimana tahap yang terakhir tidak dilakukan karena aplikasi ini baru pertama kali dioperasikan. Berikut ini penjelasan tahapan metode waterfall yang digunakan:

\subsection{Requirements Definition}

Tahapan ini digunakan untuk menganalisis kebutuhan yang diperlukan dalam pembuatan website. Analisis yang dilakukan meliputi analisis sistem yang lama atau yang sedang berjalan dan sistem baru yang direkomendasikan [10]. Analisis sistem yang sedang berjalan ini berguna untuk mengetahui kelemahan dari sistem lama, sehingga dapat diketahui siapa saja pengguna sistem dan aktifitas yang dilakukan didalam sistem. Sehingga nantinya dapat diketahui sistem baru seperti apa yang diperlukan [11][12].

\subsection{System and Software Design}

Proses pencarian kebutuhan difokuskan pada untuk mengetahui sifat dari perangkat lunak yang akan dibuat. Pemodelan fungsional menggunakan Data Flow Diagram (DFD) dan pemodelan data menggunakan Entity Relationship Diagram (ERD) [13][14]. Pada tahapan ini juga dilakukan proses untuk membuat blueprint aplikasi seperti desain basis data dan desain navigasi [15][16][17].

\subsection{Implementation and Unit Testing}

Proses yang akan dilakukan yaitu pembuatan perangkat lunak sesuai dengan perancangan yang telah dilakukan pada tahap sebelumnya [18][19].

\subsection{Integration and System Testing}

Proses pengujian akan dilakukan dengan metode Blackbox testing yang disertai dengan melakukan simulasi data. Blackbox testing adalah pengujian aspek fundamental sistem tanpa memperhatikan struktur logika internal suatu perangkat lunak [20]. Metode ini digunakan untuk mengetahui apakah perangkat lunak berfungsi dengan benar [21][22]. 


\section{Hasil dan Pembahasan}

\subsection{Analisis Sistem}

Gambar 1 di bawah ini merupakan gambaran dari alur proses penyewaan fasilitas umum yang ada pada BP PAUD dan Dikmas.

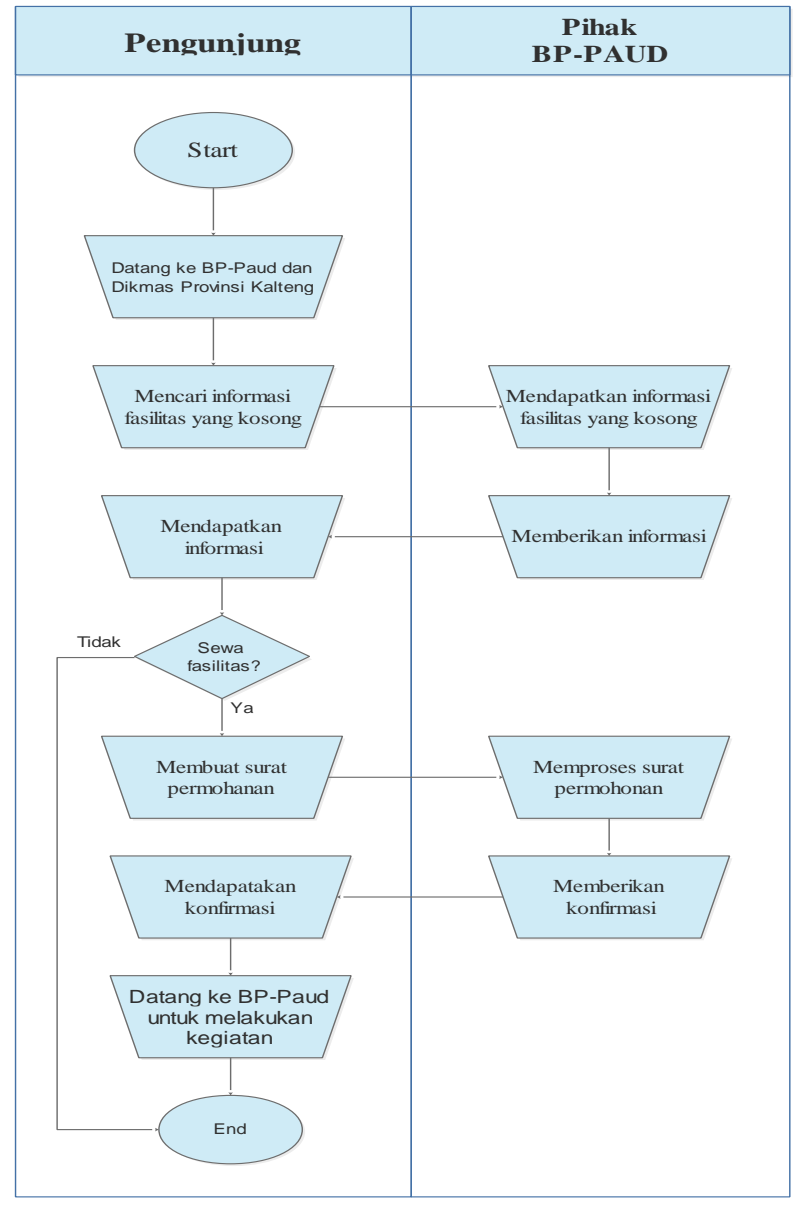

Gambar 1. Flowchart Sistem Lama

a. Kelemahan sistem lama

1) Pengunjung harus meluangkan waktu untuk mengunjungi BP PAUD dan Dikmas Provinsi Kalimantan Tengah untuk mendapatkan informasi fasilitas yang kosong untuk disewa.

2) Pengunjung harus menunggu konfirmasi dari pihak BP PAUD dan Dikmas Provinsi Kalimantan Tengah untuk proses penyewaan fasilitas.

b. Rekomendasi untuk sistem baru

1) Pengunjung membuka website penyewaan fasilitas BP PAUD dan Dikmas Provinsi Kalimantan Tengah.

2) Pengunjung dapat melihat informasi dimana saja dan kapan saja tanpa harus datang langsung ke BP PAUD dan Dikmas Provinsi Kalimantan Tengah.

3) Pengunjung atau penyewa dapat memesan fasilitas dengan mengakses website.

4) Pihak BP PAUD dan Dikmas Provinsi Kalimantan Tengah dapat memperkenalkan dan menginformasikan fasilitas yang disewakan melalui website.

Gambar 2 berikut ini merupakan gambaran dari sistem baru yang diusulkan yaitu dengan membuat aplikasi penyewaan berbasis website. 


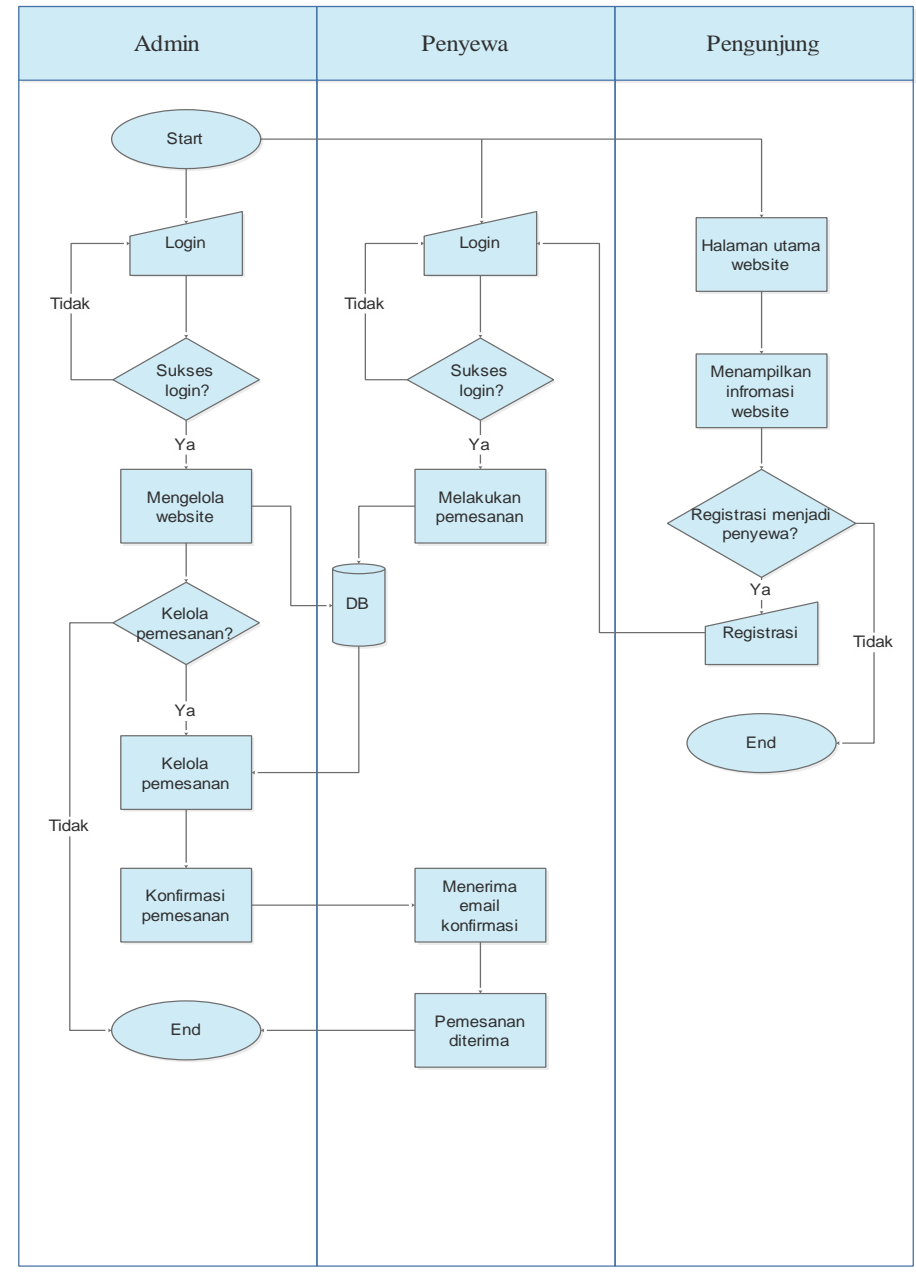

Gambar 2. Flowchart Sistem Baru

Berdasarkan dari flowchart sistem baru di atas maka pengguna dari sistem ini nanti terdiri dari admin, penyewa, dan pengunjung website. Sehingga untuk gambaran sistemnya dapat dibuat dengan diagram konteks yang tampak seperti pada gambar 3 dan untuk data flow diagram (DFD) level 1 pada gambar 4 berikut ini. 


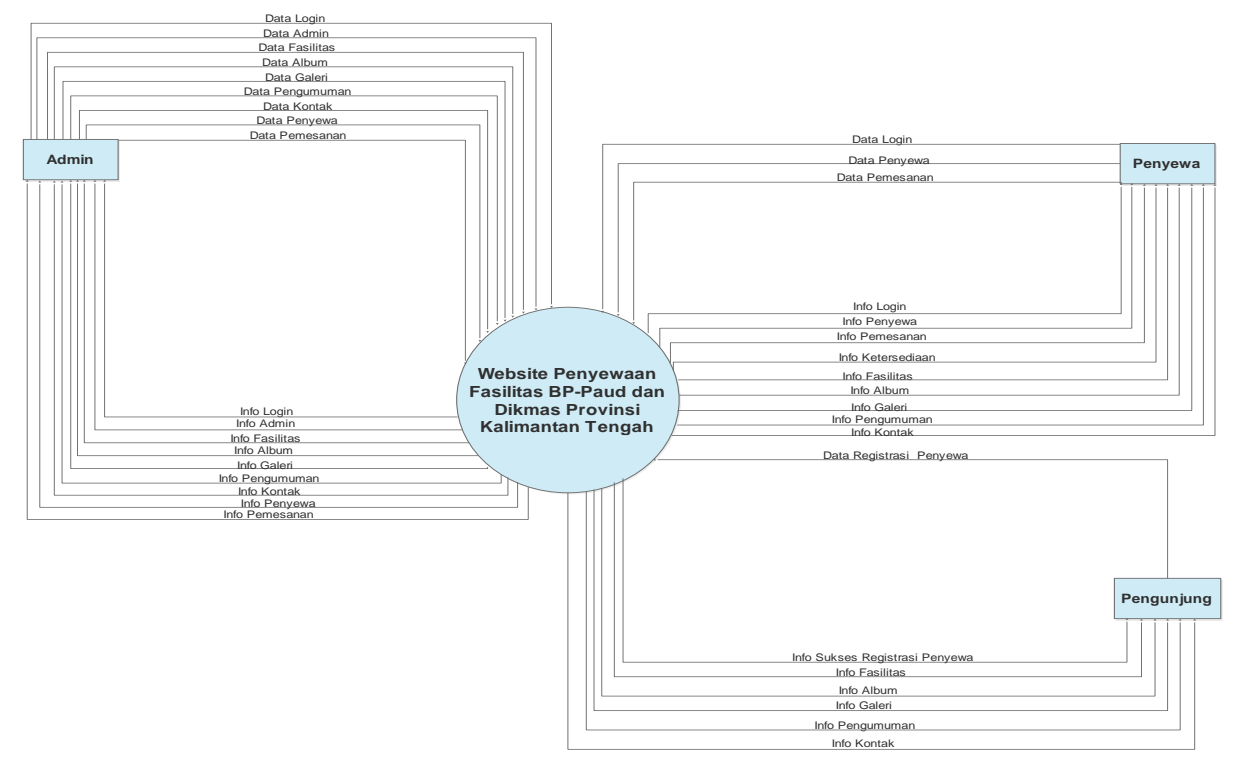

Gambar 3. Diagram Konteks Aplikasi Penyewaan Fasilitas Umum

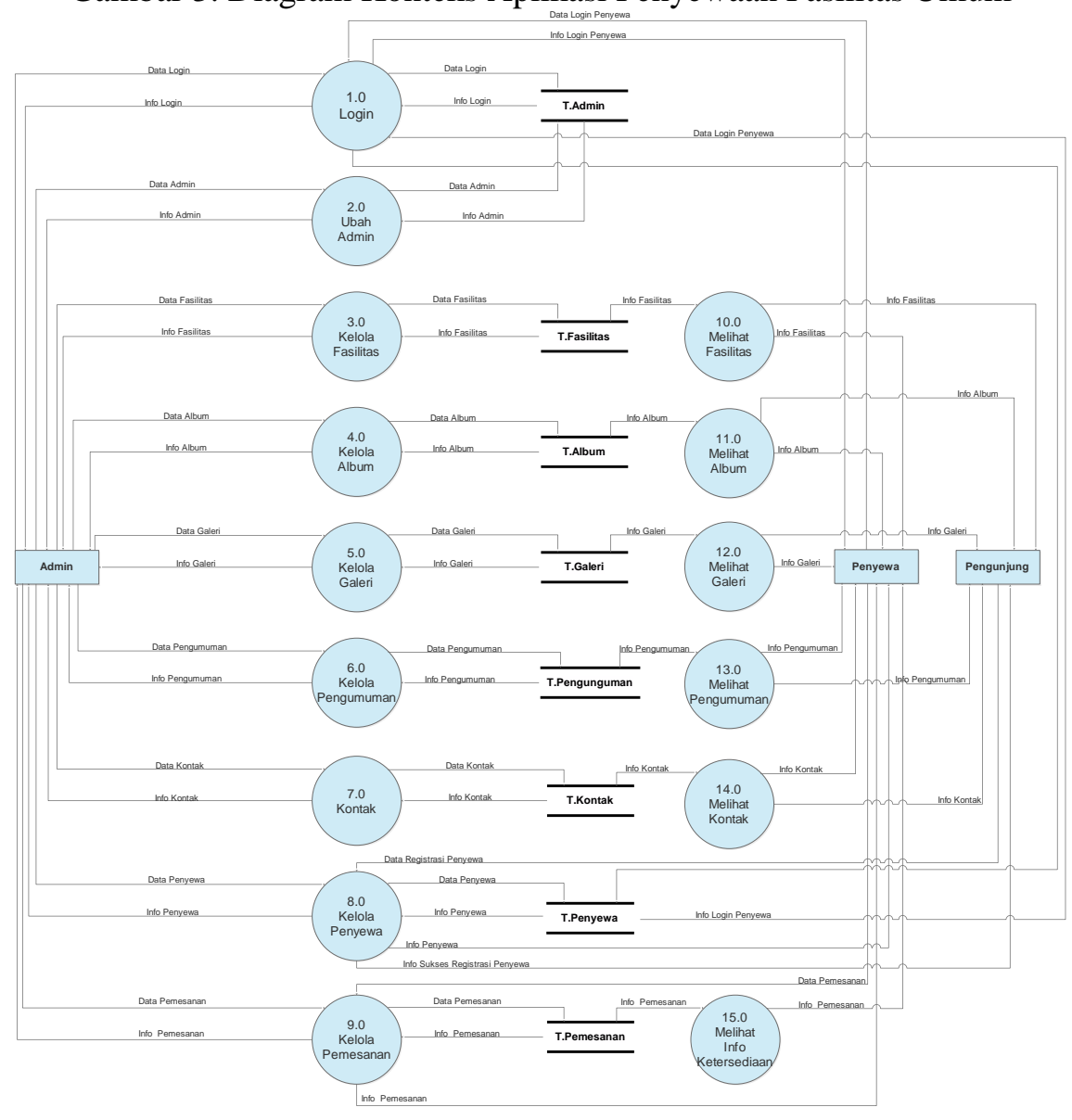

Gambar 4. DFD Level 1

Tabel 1 berikut ini merupakan tempat penyimpanan (storage) yang digunakan pada perancangan DFD level 1: 
Tabel 1. Definisi Storage

\begin{tabular}{|c|c|c|}
\hline No & Nama Penyimpanan & Keterangan \\
\hline 1 & T.Admin & $\begin{array}{l}\text { Merupakan tabel dalam basis data untuk menyimpan data akun } \\
\text { dari admin }\end{array}$ \\
\hline 2 & T.Fasilitas & Merupakan tabel dalam basis data untuk menyimpan data fasilitas \\
\hline 3 & T.Album & $\begin{array}{l}\text { Merupakan tabel dalam basis data untuk menyimpan data album } \\
\text { untuk foto penyewaan fasilitas BP Paud dan Dikmas Provinsi } \\
\text { Kalimantan Tengah }\end{array}$ \\
\hline 4 & T.Galeri & $\begin{array}{l}\text { Merupakan tabel dalam basis data untuk menyimpan foto } \\
\text { penyewaan fasilitas BP Paud dan Dikmas Provinsi Kalimantan } \\
\text { Tengah }\end{array}$ \\
\hline 5 & T.Pengumuman & $\begin{array}{l}\text { Merupakan tabel dalam basis data untuk menyimpan data } \\
\text { pengumuman }\end{array}$ \\
\hline 6 & T.Kontak & Merupakan tabel dalam basis data untuk menyimpan data kontak \\
\hline 7 & T.Penyewa & $\begin{array}{l}\text { Merupakan tabel dalam basis data untuk menyimpan akun login } \\
\text { penyewa dan data penyewa }\end{array}$ \\
\hline 8 & T.Pemesanan & $\begin{array}{l}\text { Merupakan tabel dalam basis data untuk menyimpan data } \\
\text { pemesanan }\end{array}$ \\
\hline
\end{tabular}

Untuk membuat pemodelan data selanjutnya peneliti menggunakan entity relationship diagram (ERD) yang terdapat pada gambar 6 berikut ini.
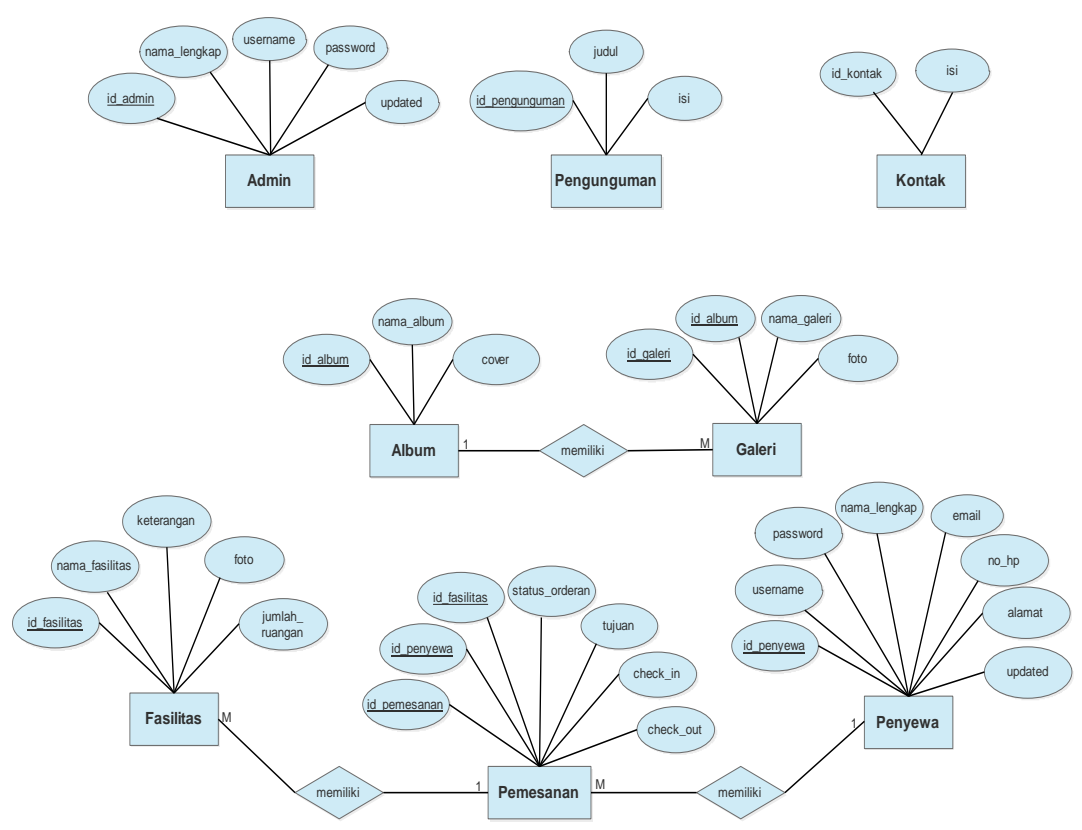

Gambar 6. ERD

\subsection{Desain}

Desain basis data yang digunakan dalam aplikasi ini dibuat dengan menggunakan MySQL. Tabeltabel yang ada yaitu tabel admin, tabel fasilitas, tabel album, tabel galeri, tabel pengumuman, tabel kontak, tabel penyewa, dan tabel pemesanan. Untuk desain navigasinya dapat dilihat pada gambar 7 , gambar 8, dan gambar 9 berikut ini. 


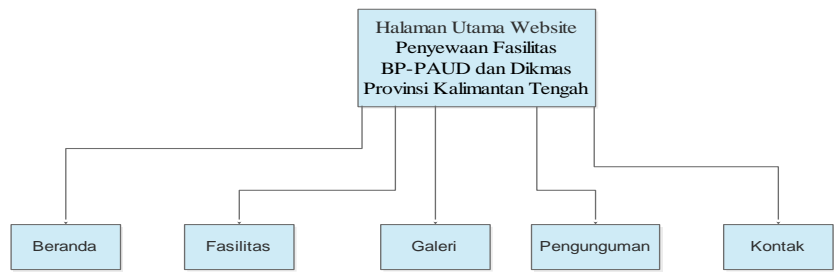

Gambar 7. Desain Navigasi Halaman Utama Pengunjung Website

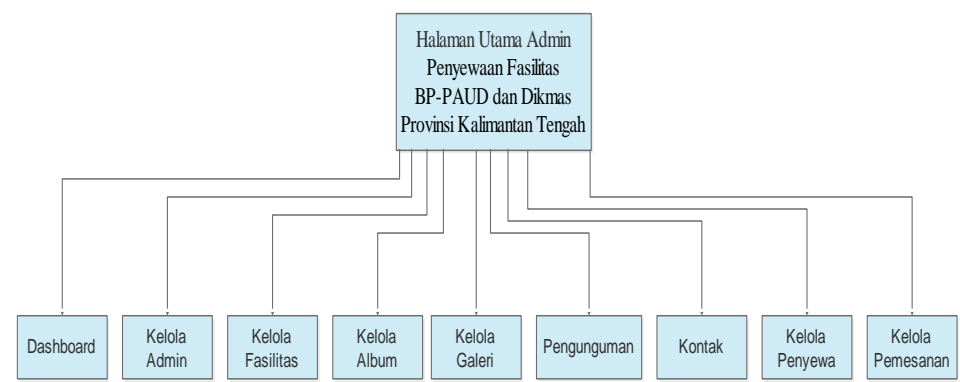

Gambar 8. Desain Navigasi Halaman Utama Admin

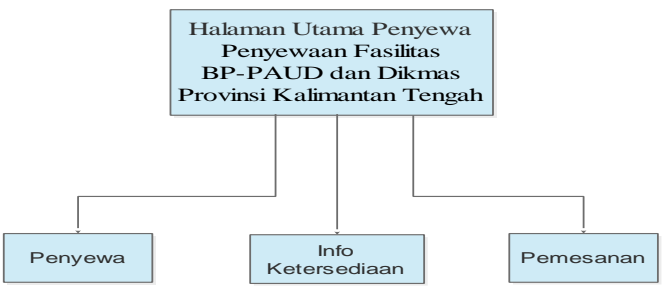

\subsection{Implementasi}

Gambar 9. Desain Navigasi Halaman Utama Penyewa

Implementasi aplikasi dilakukan sesuai dengan perancangan yang telah dilakukan pada tahap desain interface sebelumnya. Berikut ini penjelasan tentang implementasi halaman admin dan halaman penyewa.

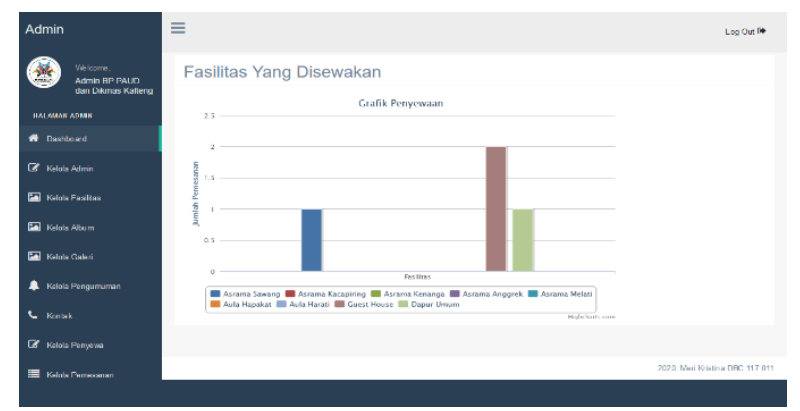

Gambar 10. Halaman Dashboard Admin

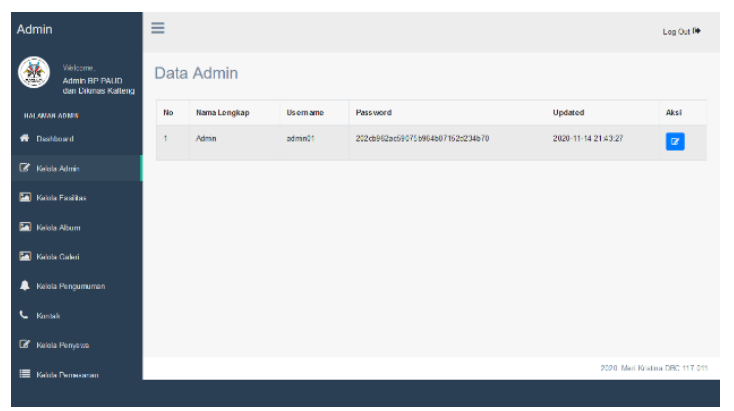

Gambar 11. Halaman Kelola Admin 


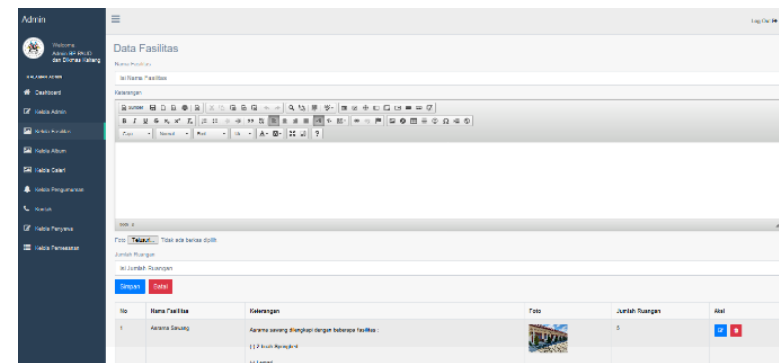

Gambar 12. Halaman Kelola Fasilitas

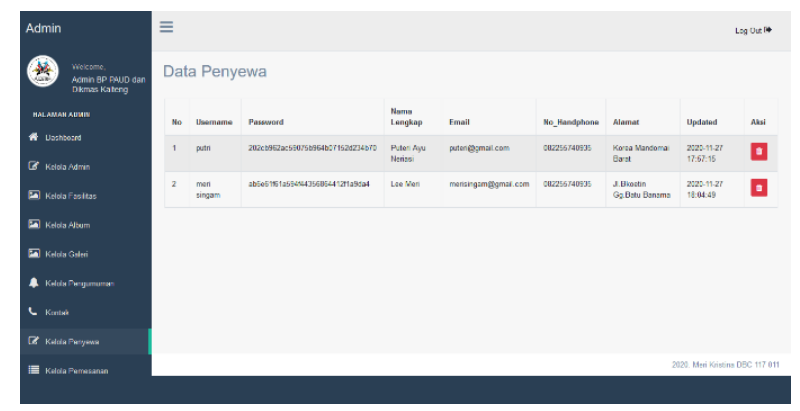

Gambar 14. Halaman Kelola Penyewa

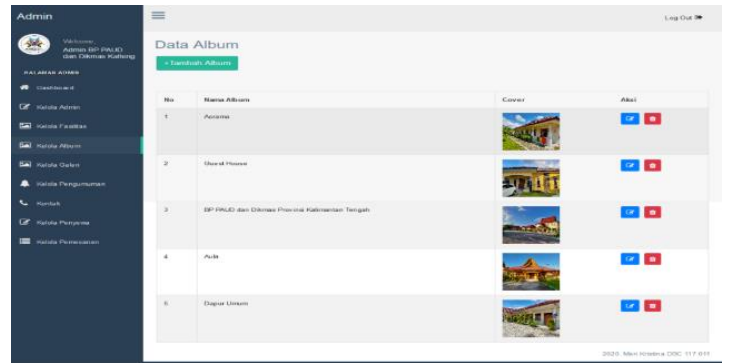

Gambar 13. Halaman Kelola Album

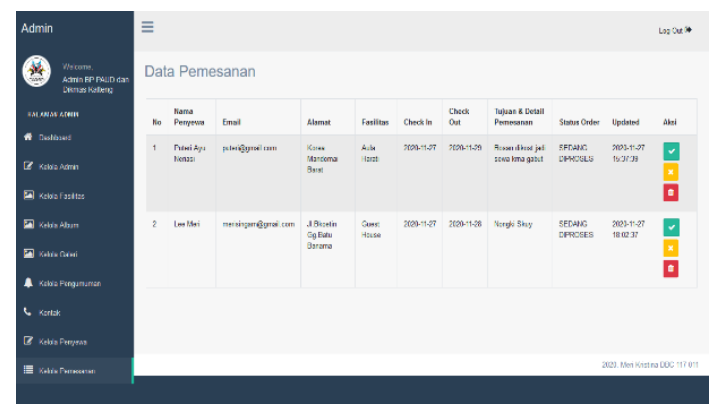

Gambar 15. Halaman Kelola Pemesanan

a. Gambar 10 menunjukkan halaman dashboard admin, yaitu halaman yang berisi informasi apa saja yang dapat dilakukan oleh admin dalam mengelola website ini.

b. Gambar 11 menunjukkan halaman kelola admin. Admin dapat mengelola akunnya. Terdapat tabel yang menampilkan identitas admin yaitu No, Nama lengkap, Username, Password, Updated dan Aksi. Terdapat satu buah aksi yaitu edit.

c. Gambar 12 menunjukkan halaman kelola fasilitas. Admin memiliki hak akses untuk kelola Fasilitas yaitu diantaranya adalah menambah, mengedit dan menghapus Data Fasilitas. Pada halaman Kelola Fasilitas terdapat tabel yang berisikan No, Nama Fasilitas, Keterangan, Foto, Jumlah Ruangan, dan Aksi di mana ada link Edit dan Hapus

d. Gambar 13 menunjukkan halaman kelola album. Admin memiliki hak akses untuk Kelola Album yaitu diantaranya adalah menambah, mengedit dan menghapus Album.

e. Gambar 14 menunjukkan halaman kelola penyewa. Admin memiliki hak akses untuk Kelola Penyewa yaitu menghapus Penyewa. Pada halaman Kelola Penyewa terdapat tabel yang berisikan No, Username, Password, Nama Lengkap, Email, No.Handphone, Alamat dan Aksi di mana ada link hapus.

f. Gambar 15 menunjukkan halaman kelola pemesanan. Admin memiliki hak akses untuk Kelola Penyewa yaitu menghapus Penyewa. Pada halaman Kelola Penyewa terdapat tabel yang berisikan No, Nama Penyewa, Email, Alamat, Fasilitas, Check In, Check Out, Tujuan \& detail Pemesanan, Status Orderan, Updated dan Aksi di mana ada link Terima, Batalkan dan Hapus.

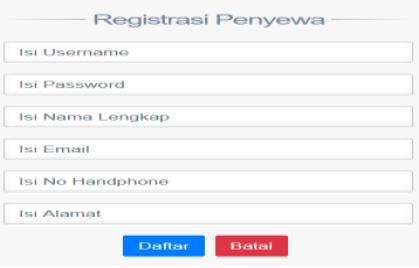

Gambar 16. Halaman Registrasi Penyewa

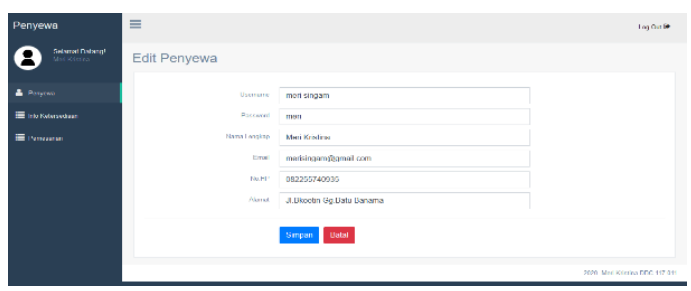

Gambar 17. Halaman Akun Penyewa 


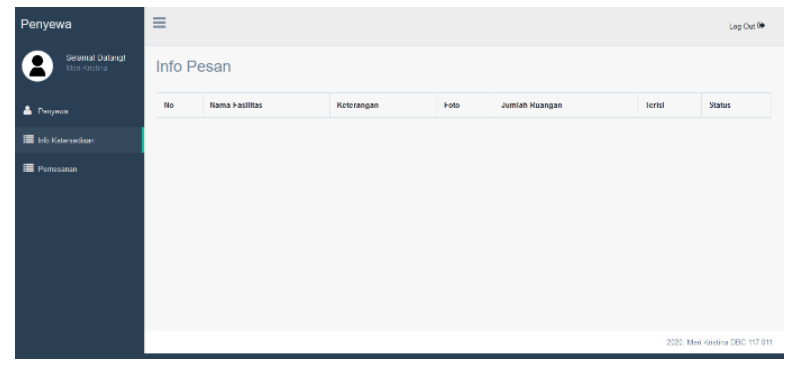

Gambar 18. Halaman Info Ketersediaan

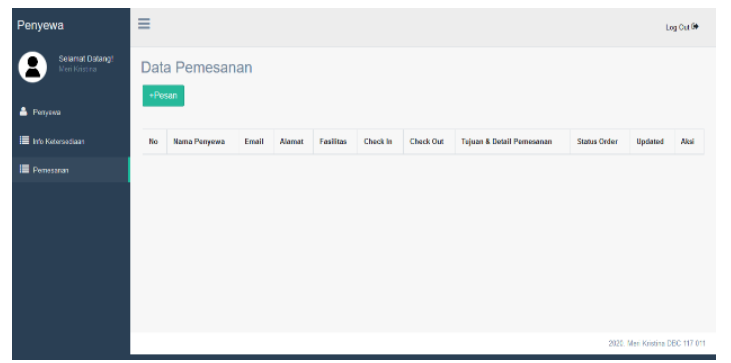

Gambar 19. Halaman Data Pemesanan

g. Gambar 16 merupakan halaman untuk registrasi penyewa agar bisa mendapatkan akun untuk mengakses halaman pemesanan fasilitas.

h. Gambar 17 merupakan halaman penyewa, terdapat Data Penyewa yang berisikan field Username, Password, Nama Lengkap, Email, No.Hp, dan Alamat yang hanya bisa diedit oleh Penyewa.

i. Gambar 18 merupakan halaman info ketersediaan, yaitu menampilkan Data Pesanan yang berisikan field Nama Fasilitas, Keterangan, Foto, Jumlah Ruangan, Terisi dan Status.

j. Gambar 19 merupakan halaman Pemesanan fasilitas yang dilakukan oleh penyewa. Pada halaman Pemesanan tererdapat tabel yang berisikan Data Pemesanan dan Aksi di mana ada link Batalkan.

\subsection{Pengujian}

Setelah melakukan implementasi, dilakukan pengujian terhadap sistem dengan tujuan untuk melihat semua kesalahan dan kekurangan yang ada pada sistem. Pengujian sistem pada website ini dilakukan dengan menggunakan metode Black Box. Pada pengujian ini fokus pada kebutuhan fungsional dan outputnya sesuai dengan yang diharapkan atau sebaliknya. Dalam pengujian sistem ini digunakan metode Black Box yaitu dilakukan dengan membuat kasus yang bersifat mencoba semua fungsi dengan memakai perangkat lunak apakah sesuai dengan spesifikasi yang dibutuhkan. Kasus uji yang dibuat untuk melakukan pengujian Black Box dibuat dengan kasus benar dan kasus salah. Berikut beberapa proses yang akan dilakukan pengujian yaitu :

1) Kegiatan yang dilakukan oleh Admin

2) Kegiatan yang dilakukan oleh Pengunjung

3) Kegiatan yang dilakukan oleh Penyewa

\section{Kesimpulan}

Dalam membangun website ini menggunakan metodologi pengembangan perangkat lunak Waterfall yang memiliki tahapan yaitu Requirements Definition yang dilakukan dengan pembuatan Flowchart. System and Software Design dilakukan pembuatan Data Flow Diagram (DFD) dan Enity Relationship Diagram (ERD), Implementation and Unit Testing dengan bahasa pemrograman yang digunakan yaitu HTML, PHP, CSS, Bootstrap, Javascript dan MySQL dan Integration and System Testing. Metode testing yang digunakan adalah metode Blackbox. Dari hasil pengujian ini dapat disimpulkan bahwa website ini dapat berjalan sesuai dengan fungsi. Hasil akhir dari penelitian ini menyatakan tercapainya tujuan yang telah dilaksanakan seperti adanya beberapa fitur yang digunakan dengan tepat sesuai kegunaannya. Adanya Aplikasi Penyewaan Fasilitas BP PAUD dan Dikmas Provinsi Kalimantan Tengah Berbasis Website ini dibuat dengan tujuan untuk memfasilitasi pihak instansi khususnya Subbag Umum bagian Keuangan BP-PAUD dan Dikmas Provinsi Kalimantan Tengah untuk mendata proses penyewaan fasilitas dan dapat mempercepat proses penyewaan.

\section{Daftar Pustaka}

[1] Rohi Abdulloh, Easy \& Simple Web Programming. Jakarta: Elex Media Komputindo, 2016.

[2] M. Rudyanto Arief, Pemrograman Web Dinamis Menggunakan PHP dan MySQL. Yogyakarta: Andi Ofset, 2011. 
[3] Agung Baitul Hikmah, Cara Cepat Membangun Website Dari Nol. Yogyakarta: Andi Ofset, 2015.

[4] P. B. A. A. Putra, V. H. Pranatawijaya, W. Widiatry, and N. Natalius, "Analisis Dan Desain Perangkat Lunak Generate File Akun Uang Kuliah Tunggal (UKT) Universitas Palangka Raya," J. Teknol. Inf. J. Keilmuan dan Apl. Bid. Tek. Inform., vol. 12, no. 1, pp. 48-55, 2018, doi: 10.47111/jti.v12i1.523.

[5] N. N. K. Sari, W. Widiatry, and P. B. A. A. Putra, "Sistem Informasi Kepegawaian UPT Kesatuan Pengelolaan Hutan Produksi Kapuas Tengah UNIT XI," J. Inform., vol. 7, no. 2, pp. 183-191, 2020.

[6] W. Widiatry, "Perancangan Perangkat Lunak Pendaftaran dan Penjadwalan Ujian Skripsi Pada Fakultas Kedokteran Universitas Palangka Raya Berbasis Website," J. Teknol. Inf., vol. 14, no. 2, pp. 150-160, 2020.

[7] W. Widiatry and A. Nugraha, "Rancang Bangun Website E-Learning SMAN 1 Palangka Raya," J. Teknol. Inf., vol. 12, no. 1, pp. 57-62, 2018.

[8] W. Widiatry and N. O. Anggraini, "Pengembangan Website Pengelolaan Praktikum Pada Program Studi Biologi Fakultas Matematika Dan Ilmu Pengetahuan Alam Universitas Palangka Raya," J. Teknol. Inf., vol. 15, no. 1, pp. 60-71, 2021.

[9] I. Sommerville, Software Engineering (9th Edition). USA: Pearson Education, 2011.

[10] R. S. Pressman, Rekayasa Perangkat Lunak: Pendekatan Praktisi Buku I. Yogyakarta: Andi Ofset, 2015.

[11] W. Widiatry, N. N. K. Sari, V. H. Pranatawijaya, and P. B. A. A. Putra, "Penerapan Algoritma Levenshtein Distance Untuk Pencarian Pada Sistem Informasi Perpustakaan Fakultas Kedokteran Universitas Palangka Raya,” J. SAINTEKOM, vol. 9, no. 1, pp. 66-82, 2019.

[12] R. A. S. and Shalahudin, Rekayasa Perangkat Lunak: Terstruktur Dan Beorientasi Objek. Bandung: Penerbit Informatika, 2013.

[13] W. Widiatry, "Pengembangan Aplikasi Kartu Rencana Studi Online Pada Jurusan Pendidikan Luar Sekolah Universitas Palangka Raya,” J. Inform., vol. 14, no. 1, pp. 83-93, 2020.

[14] W. Widiatry, N. N. K. Sari, and A. Ananingtyas, "Sistem Penunjang Keputusan Pemilihan Siswa Berprestasi Menggunakan Metode Weighted Product (Studi Kasus: SMA Muhammadiyah Kecamatan Katingan Tengah)," J. Teknol. Inf., vol. 12, no. 2, pp. 80-86, 2018.

[15] P. B. A. A. Putra, V. H. Pranatawijaya, W. Widiatry, and N. N. K. Sari, "Pengembangan Perangkat Lunak Generate File Data Kehadiran Pegawai Universitas Palangka Raya," Anterior J., vol. 18, no. 2, pp. 182-189, 2019.

[16] W. Widiatry, "Rancang Bangun Website Sistem Informasi Praktikum Jurusan Teknik Informatika Univeritas Palangka Raya," J. SAINTEKOM, vol. 6, no. 2, pp. 12-24, 2017.

[17] V. H. Pranatawijaya, W. Widiatry, N. N. K. Sari, and P. B. A. A. Putra, "Sistem Informasi Geografis Mencari Rute Lokasi Travel Di Kota Palangka Raya Berbasis Website," J. Teknol. Inf., vol. 13, no. 1, pp. 71-78, 2019.

[18] W. Widiatry and N. N. K. Sari, "Rancang Bangun Website untuk Memeriksa Plagiat E-Journal Fakultas Kedokteran Universitas Palangka Raya," J. CoreIT, vol. 5, no. 2, pp. 36-43, 2019.

[19] P. B. A. A. Putra, V. H. Pranatawijaya, W. Widiatry, and L. Lisa, "Rancang Bangun Sistem Informasi Pencarian Data Mahasiswa dan Dosen pada Fakultas Hukum Universitas Palangka Raya," J. Teknol. Inf., vol. 11, no. 2, pp. 36-45, 2019.

[20] H. Bhasin, E. Khanna, and S. Sudha, "Black Box Testing based on Requirement Analysis and Design Specifications," Int. J. Comput. Appl. (0975 - 8887), vol. 87, no. 18, 2014.

[21] V. H. Pranatawijaya, P. B. A. A. Putra, W. Widiatry, and N. N. K. Sari, "Pengembangan Perangkat Lunak Generate File Akun Uang Kuliah Tunggal (UKT) Universitas Palangka Raya," J. SAINTEKOM, vol. 8, no. 2, pp. 166-178, 2018.

[22] N. N. K. Sari, W. Widiatry, and N. Chitayae, "Sistem Pendukung Keputusan untuk Seleksi Penerima Beasiswa BBP-PPA dengan Metode TOPSIS berbasis Web," Anterior J., vol. 18, no. 1, pp. 86-91, 2018. 